\title{
DARI REFORMASI KEPADA TRANSFORMASI
}

Relevansi Gerakan Reformasi Abad ke-16 bagi Transformasi Masyarakat Indonesia

\section{Agustinus M. L. Batlajery}

\section{Pendahuluan}

R eformasi berarti perubahan radikal untuk perbaikan di bidang politik, Rsosial atau agama dalam suatu masyarakat atau negara. Dengan reformasi orang melakukan perubahan radikal untuk memperbaiki tata kehidupan di dalam satu atau beberapa bidang kehidupan. Yang diubah atau dibaharui adalah sistem, paradigma atau pola pikir yang sangat mendasar. Sedangkan transformasi berarti perubahan rupa atau bentuk. Dengan transformasi orang mengubah rupa atau bentuk, sifat, struktur atau fungsi dari sesuatu. Keduaduanya mempunyai tujuan yang sama yakni perbaikan. Baik reformasi maupun transformasi dilakukan guna memperbaiki tata kehidupan suatu masyarakat di bidang politik, sosial dan keagamaan. Bahkan dapat diperluas pula ke bidang-bidang kehidupan lainnya seperti ekonomi dan kebudayaan.

Reformasi dapat menghasilkan transformasi. Perubahan radikal dapat bermuara pada perubahan bentuk, struktur, sifat, atau fungsi. Perubahan masyarakat yang diidam-idamkan dapat dicapai melalui sebuah reformasi. Rupanya hal inilah yang dimaksudkan dengan judul yang ditawarkan kepada saya dalam rangka merayakan 65 tahun Pdt. Prof. Dr. Samuel Benyamin Hakh. Pertanyaan yang timbul adalah reformasi manakah yang dimaksudkan di sini? 
Sebab di Indonesia, kita juga mengenal istilah reformasi yakni reformasi di bidang politik pemerintahan dan kenegaraan yang terjadi pada tahun 1998 pada masa pemerintahan rezim Orde Baru. Pada waktu itu, euforia reformasi menguat di kalangan masyarakat. Sementara dalam sejarah kekristenan kita pun mengenal reformasi Gereja abad ke-16 yang terjadi di Eropa sebagai sebuah reformasi keagamaan. Tokoh-tokoh utamanya adalah Martin Luther dan Yohanes Calvin. Subjudul tulisan ini kiranya sudah menjawab pertanyaan di atas yakni reformasi gereja abad ke-16. Jelas bahwa pembahasan ini akan berfokus ke sana. Untuk itu, ada baiknya juga bila kita tidak hanya membahas reformasi abad ke-16 dalam rangka transformasi masyarakat kala itu. Kita hendaknya melihat pula reformasi di Indonesia yang terjadi tahun 1988 sebagai bandingannya. Sesudah itu barulah kita membahas relevansi dari reformasi abad ke-16 itu bagi transformasi masyarakat Indonesia yang telah melewati reformasinya sendiri pada tahun 1998.

\section{Reformasi Abad ke-16}

Reformasi Gereja pada abad ke-16 di Eropa bukan saja terjadi di Jerman melainkan menyebar susul-menyusul ke beberapa negara lain seperti Swiss, Prancis, dan Inggris. Konteks berlangsungnya reformasi di tiap tempat itu pun tidak selalu sama (Aritonang, 2007: 16-59). Di sini tidak dapat dibahas konteks masing-masing tempat itu mengingat ruang yang terbatas bagi tulisan ini. Yang akan dikemukakan hanyalah latar belakang dan konteks reformasi gereja pada abad ke-16 secara umum saja.

Dalam pengamatannya terhadap konteks reformasi Gereja abad ke-16, Jan S. Aritonang menemukan bahwa situasi kerohanian atau kegerejaan, maupun situasi sosial, politik, kebudayaan, dan bahkan ekonomi di Eropa pada masa itu erat kaitannya dengan reformasi Gereja yang dicanangkan Luther (Aritonang, 2016: 28). Situasi-situasi ini mendorong terjadinya reformasi. Namun, Luther bukanlah orang pertama yang mencanangkan reformasi gereja di Eropa. Sudah ada beberapa perintis gerakan reformasi gereja yang tampil sebelum dia. Mereka adalah John Wycliffe (1329-1384) di Inggris dan Johannes Hus (1373-1415) di Bohemia (kini Ceko). Hanya saja situasi pada waktu itu belum cukup kondusif bagi mereka untuk melaksanakan pembaruan yang me- 
nyeluruh. Posisi gereja tradisional (traditional church) ${ }^{1}$ di Roma masih cukup kuat. Masyarakat pun belum begitu antusias mengharapkan suatu keadaan yang baru. Lagi pula, belum ada kerajaan yang kuat yang bisa membebaskan diri dari dominasi Paus di Roma (Aritonang, 2016: 29). Selain itu, menurut Van den End, pemahaman para reformator sebelum Luther tentang Injil juga masih sama dengan pemahaman Gereja tradisional waktu itu. Akibatnya, dari segi teologi mereka tidak memiliki titik tolak yang kuat. Tentang pemikiran teologis para reformator sebelum Luther ini Van Den End berkata:

Kedua orang ini ingin membarui gereja. Dan tokoh-tokoh dari Pembaruan Gereja yang nanti diusahakan oleh Luther itu menghormati mereka sebagai orang-orang saleh, yang menganjurkan banyak hal yang baik. Namun tidak ada di antaranya yang - seperti Luther nanti - merombak sistem teologi dan tata gereja Abad Pertengahan secara radikal, dari akarnya. Sebabnya ialah bahwa mereka memandang Injil sebagai hukum, "Hukum Kristus" yang harus orang ikuti supaya selamat. Jadi walaupun mereka hendak melepaskan Injil dari kulit tradisi yang berlaku dalam Gereja Roma, namun secara asasi mereka memandang Injil dengan cara yang sama, mereka tidak mempunyai titik tolak teologi yang sungguh-sungguh baru (End 1982, 150; Aritonang 2007,10).

Sekarang baiklah kita kembali ke situasi kerohanian dan kegerejaan yang mendorong dilakukannya reformasi gereja. Menurut Van den End penyebab timbulnya pembaharuan gereja adalah perbedaan antara teologi dan praktik gereja dengan ajaran Alkitab sesuai penemuan Luther. Sementara itu, peristiwa yang memicu diadakannya reformasi dalam gereja adalah penjualan surat-surat penghapusan siksa oleh Tetzel di Jerman (End, 1982:166). Jadi persoalan pokok dari reformasi gereja terletak pada teologi dan praktik Gereja, yang menurut Luther, tidak sesuai dengan kesaksian Alkitab.

Teologi yang tidak sesuai dengan ajaran Alkitab itu adalah pandangan

1 Menurut para ahli sebelum Konsili Trente (atau Trento) kita belum dapat berbicara tentang Gereja Katolik Roma yang kemudian berkembang sampai bentuknya yang sekarang. Menurut para ahli, Gereja Katolik Roma baru berbentuk pada Konsili Trente (1545-1563). Sebelum konsili tersebut kita hanya berbicara tentang Gereja Tradisional di Roma (Traditional Church in Rome) (Tanner, 2003; Batlajery 2010, 22). 
bahwa keselamatan manusia ditentukan oleh Gereja, dalam hal ini Paus, dan bahwa untuk memperolehnya manusia harus ikut berperan dalam bentuk beramal atau berbuat baik. Keselamatan tidak semata-mata bergantung pada rahmat Allah saja. Oleh karena itu, manusia tidak dapat semata-mata mengandalkan rahmat Allah dalam upayanya memperoleh keselamatan. Rahmat Allah dan upaya manusia harus berjalan bersamaan. Bila Pelagius mengajarkan bahwa manusia bertanggung jawab atas keselamatannya sendiri dan oleh karena itu ia harus berbuat baik bila ingin selamat lalu mengabaikan rahmat Allah maka Gereja tradisional di Roma memasukkan unsur rahmat Allah ke dalam teologi dan ajarannya. Teologi dan ajaran ini kemudian disebut Semi-Pelagianisme. ${ }^{2}$ Jadi, teologi dan ajaran gereja waktu itu tentang keselamatan merupakan penggabungan antara pandangan Augustinus dan Pelagius, yang pada satu pihak Alkitabiah (Augustinus) tetapi pada pihak lain berlandaskan tradisi (Pelagius).

Sementara itu, praktik gereja yang menyimpang waktu itu tampak dalam bentuk penjualan surat-surat penghapusan siksa oleh Johann Tetzel. Menurut gereja, bila seseorang ingin selamat melintasi purgatorium (api penyucian) maka ia harus banyak berbuat amal kebaikan bagi gereja. Salah satunya adalah dengan membeli surat penghapusan siksa yang dijual pejabat gereja, sesuai dengan timbangan dosanya (Aritonang, 2016: 29). Teologi dan praktik di atas, menurut Luther, tidak sesuai dengan ajaran Alkitab.

Rupanya pemimpin gereja waktu itu menggunakan otoritas yang ada padanya untuk menciptakan sebuah ajaran dan praktik demi melegitimasi motif melanggengkan dan memamerkan kekuasaan religius dan politiknya. Hal ini terutama terjadi karena waktu itu kepausan membutuhkan banyak dana untuk membiayai perang-perang salib dan pembangunan Katedral Santo Petrus yang megah. Mereka harus mencari cara bagaimana dapat mengumpulkan uang sebanyak-banyaknya, selain upeti ataupun pajak yang diterima dari wilayah-wilayah di bawah kekuasaan kepausan. Karena itu, seperti dijelaskan di atas, keluarlah ajaran dan praktik gereja yang oleh Luther dinilai menyimpang dari Alkitab. Di sini agama digunakan untuk

2 Ajaran Pelagius tentang keselamatan dapat dibaca dalam buku Gagasan Yang Menjadi Peristiwa (Eddy Kristiyanto, 2002: 101-110); dan buku Sejarah Gereja yang khusus membahas pertikaian antara Pelagius dan Augustinus (Berkhof \& Enklaar, 1986: 67-70). 
kepentingan politik kekuasaan.

Selain teologi dan praktik sebagaimana diuraikan di atas, situasi kerohanian dan kegerejaan dalam Gereja tradisional waktu itu memicu timbulnya keresahan. Klaim supremasi Gereja yang kemudian meluas sampai ke bidang politik di seluruh Eropa oleh Uskup atau Paus di Roma yang sudah dimulai sejak abad ke-5, telah menyebabkan ketidaknyamanan di mana-mana. Akibatnya ada di antara para pemimpin Gereja dan para raja setempat yang bersikap "mbalelo" terhadap Paus di Roma, kendati tidak tampak secara terangterangan. Keadaan ini diperparah oleh perilaku para pejabat Gereja yang jauh dari kesucian dan kesalehan serta ketergantungan penuh pada rahmat Allah. Banyak dari antaranya yang hidup bergelimang kemewahan dan melakukan perbuatan amoral. Sementara pelayanan, pembinaan dan penggembalaan kepada umat sangat diabaikan dikarenakan anggapan bahwa setiap orang sudah menjadi anggota Gereja secara otomatis sejak lahir (Aritonang, 2016: 29). Keadaan ini mendorong bangkitnya keinginan berbagai kalangan, terutama pihak yang menjunjung tinggi kemurnian ajaran Gereja untuk melakukan pembaruan. Dalam konteks ini Alister McGrath mengatakan bahwa suatu aspek penting dari keadaan keagamaan di Jerman pada abad ke-15 adalah fenomena antipapalisme dan anti klerikalisme (McGrath, 1997: 35).

Situasi sosial-politik tak kalah penting untuk disebutkan. Pudarnya citacita mempersatukan semua orang Kristen di Eropa, munculnya semangat emansipasi politik di hampir seluruh Eropa, kecenderungan para raja yang tidak mau tunduk kepada kaisar yang dipandang sebagai antek Paus serta bangkitnya semangat nasionalisme yang menekankan kesetaraan antar bangsa, kesemuanya merupakan situasi di bidang sosial politik kala itu. Aritonang menggambarkannya demikian:

"Cita-cita persatuan semua orang Kristen di bawah pimpinan Paus sudah pudar. Timbul semangat emansipasi politik di hampir seluruh Eropa. Setiap raja ingin mengatur urusan negeri atau wilayah kekuasaannya masingmasing, dan tidak mau lagi mengakui klaim supremasi Gereja atau Paus atas negara. Khususnya di Jerman memang masih ada Kaisar yang setia pada Paus dan mengklaim kekuasaan atas seluruh Jerman. Tetapi dalam kenyataannya negeri itu terbagi-bagi atas sekian banyak wilayah atau negara bagian yang dipimpin oleh raja atau pangeran yang punya otonomi dan kedauatannya sendiri, termasuk di bidang keagamaan. Raja-raja itu tidak suka tunduk kepada kaisar dan kaisar lebih sering dipandang sebagai antek Paus ketim- 
bang sebagai tokoh pemersatu Jerman. Dalam pada itu, di kalangan bangsa Jerman bangkit semangat nasionalisme yang menekankan kesetaraan dengan-bahkan keunggulan atas-bangsa-bangsa lain, dan karena itu tidak mau lagi tunduk di bawah kekuasaan yang berasal dari negara atau bangsa lain, dalam hal ini Paus di Roma. (Aritonang, 2016: 30)

Bidang lainnya yang patut pula disebutkan adalah bidang kebudayaan di mana Renaisans yang tampil sejak abad ke-15 memberikan pengaruh yang besar. Renaisans mendorong orang untuk kembali ke kejayaan masa lampau dari zaman kejayaan Yunani-Romawi. Untuk menemukan kejayaan masa lalu tersebut, orang perlu menggali sumber-sumber yang asli lalu mengembangkannya secara baru. Semboyan yang terkenal untuk menggambarkan semangat ini adalah ad fontes yang berarti kembali ke dokumendokumen yang sah dari kekristenan yaitu penulis-penulis patristis dan yang paling utama adalah Alkitab (McGrath 1997,57). Luther secara serius mendalami Alkitab dan tulisan-tulisan para Bapa Gereja. Hasilnya adalah ia menemukan makna Roma 1:16-17 dan mengangkat ke permukaan pandangan Augustinus tentang rahmat Allah.

Selain kembali ke sumber-sumber asli yang antara lain Alkitab, arus lain dari Renaisans adalah menggabungkan filsafat Yunani dengan iman kristiani. Upaya ini pada gilirannya melahirkan paham Humanisme. Salah satu tokoh yang terkenal dari faham ini adalah Desiderius Erasmus. Karena itu, Humanisme, yakni Humanisme Kristen, tidak dapat dilepaspisahkan dari reformasi. Perlu dicatat juga bahwa pada zaman Renaisans berkembang sikap positif terhadap perkembangan ilmu pengetahuan dan teknologi modern. Itulah sebabnya penemuan mesin cetak pada abad ini oleh Johannes Gutenberg disambut gembira di Eropa dan dipakai mencetak tulisan-tulisan Luther untuk disebarluaskan (Aritonang, 2016: 31).

Sejak abad ke-15 perekonomian di Eropa Barat mengalami perkembangan pesat, terutama di bidang perdagangan dan industri. Bangkitnya kelas para pedagang dan pengusaha pada penghujung abad ini mewarnai kegiatan perekonomian. Merekalah yang menjadi cikal-bakal kapitalisme dan yang kemudian menggeser dominasi feodalisme dalam mana Gereja telah terlibat berabad-abad lamanya. Bahkan, Gereja dipandang sebagai soko guru sistem tersebut (Artionang 2016, 31). Pada masa ini feodalisme dikritik karena dipandang sudah tidak cocok lagi dengan perkembangan zaman. Sejalan de- 
ngan itu, Gereja sebagai soko guru sistem feodalisme juga menerima kritikan.

Reformasi lahir dari situasi-situasi semacam ini. Meskipun tujuan utamanya membarui ajaran dan praktik Gereja, namun ibarat ladang yang subur bagi bertumbuh kembangnya suatu tanaman, demikianlah reformasi dapat tumbuh dan berkembang mencapai sasarannya berkat situasi-situasi ini.

\title{
Martin Luther, Reformasi Gereja dan Lahirnya Gereja Reformasi
}

Tiga kalimat berikut ini dapat meringkaskan riwayat hidup Martin Luther, begitu kata Timothy George. Ketiga kalimat tersebut adalah sebagai berikut.

\begin{abstract}
Martin Luther was born on November 10, 1483, in Eisleben, the son of the middle-class silver miner. Destined for the study of law, he turned to the monastery where after many struggles he developed a new understanding of God, faith and the church. This involved him in conflict with the papacy, followed by his excommunication and the founding of the Lutheran Church, over which he presided until his death in 1546 (George, 1992: 51).
\end{abstract}

Eisleben terletak di Jerman Timur (Lane, 1990: 130). Di situ berdiam keluarganya, yang menurutnya miskin (End, 1982: 156), tetapi sangat setia kepada Gereja tradisional di Roma. Ia dibaptis dengan nama Martinus. Dalam keluarga yang setia itu, ia dididik secara ketat dalam ajaran Gereja. Sesungguhnya ia sedang mempersiapkan diri untuk menjadi ahli hukum di Universitas Erfurt ketika suatu kejadian nyaris merenggut nyawanya. Peristiwa itu begitu menakutkannya sehingga ia memutuskan menjadi rahib. Ia lalu bergabung dengan frater-frater Augustinus di Erfurt dan belajar teologi di situ menurut "jalan modern" yang diajarkan oleh murid-murid Gabriel Biel (Lane, 1990: 137).

Sesuai dengan ajaran Gereja waktu itu, ia dididik untuk takut kepada Tuhan. "Sejak masa muda saya, saya dididik sedemikian rupa, hingga saya harus menjadi pucat-pasi dan takut bila saya mendengar nama Kristus disebut saja, karena saya hanya diajar untuk memandang Dia sebagai seorang Hakim yang keras dan pemurka" (End, 1982: 156), demikian katanya. Kepadanya diajarkan bahwa supaya Allah berkenan dan kita menerima anugerah-Nya, 
kita harus berusaha sebaik-baiknya. Jadi, pandangan tentang Allah yang penuh kasih, mahamurah, pengasih, dan penyayang tidak ada dalam pikirannya. Allah merahmati seseorang bila orang itu berusaha berbuat baik. Luther bertumbuh dalam pemahaman teologis tentang Allah yang demikian itu.

Pada umur 21 tahun ia memutuskan untuk studi dan menjadi seorang rahib. Keputusan itu diambilnya ketika dalam sebuah perjalanan mengunjungi orangtuanya di Erfurt, guruh dan halilintar menyambarnya. Dalam rasa takut dan gemetar yang amat sangat ia berseru: "Santa Anna yang baik, tolonglah Aku. Aku mau menjadi rahib kalau aku selamat!" Peristiwa itu terjadi pada tanggal 2 Juni 1505 (Berkhof \& Enklaar, 1986: 121). Janji ini ditepatinya dengan masuk Biara Augustin, ${ }^{3}$ seperti telah disinggung di atas.

Di sana ia terkenal sebagai seorang biarawan yang cerdas. Pemimpin biara itu lalu menugaskannya belajar teologi. Pada tahun 1512 ia berhasil merasih gelar doktor di bidang Kitab Suci dan diangkat sebagai guru besar ilmu teologi di Universitas Wittenberg dengan tugas utama menafsir Kitab Suci. Karena tugas utamanya menafsir Alkitab maka ia harus memeriksa naskah asli dalam bahasa Ibrani dan Yunani. Ini sejalan dengan jiwa dan semangat ad fontes.

Pergumulan berat Luther sehubungan dengan ajaran Gereja dalam kajiankajian biblisnya adalah pertanyaan tentang keselamatan. Bagaimana caranya agar aku memperoleh rahmat Allah agar aku selamat? Atau dengan perkataan lain, bagaimanakah aku bisa mendapat suatu Allah yang rahmani? (Berkhof \& Enklaar, 1986: 123). Itu adalah pertanyaan yang mengiang terus di telinganya setiap hari. Pada satu pihak Gereja mengajarkan bahwa keselamatan sebagai rahmat Allah bisa diperoleh. Namun, manusia tidak dapat memperolehnya secara cuma-cuma. Harus ada perbuatan baik yang menyertainya. Karena Allah itu menimbang-nimbang jasa seseorang maka tak bisa tak ada sesuatu jasa berupa perbuatan baik dari orang itu untuk dijadikan pertimbangan Allah. Pada pihak lain ia menemukan bahwa Roma 1:16-17 mengajarkan lain. Maka ia mengalami ketegangan dan kegelisahan. Ia telah berusaha keluar dari ketegangan yang menggelisahkan hatinya itu dengan cara berpuasa, berjaga pada waktu malam, menyiksa diri, berdoa dan lain-lain selama berada di biara. Meskipun demikian, ia tidak menemukan jawaban. Malah justru ia merasa

3 Disebut juga biara Ordo Eremit Augustin (Berkhof \& Enklaar 1986, 121) 
semakin jauh dari Allah (Berkhof \& Enklaar, 1986: 125).

Sampai pada suatu saat ketika ia membaca dan merenungkan secara mendalam Roma 1:16-17. Dari hasil tafsirannya terhadap nas itu ia berkesimpulan bahwa bukan karena kebenaran Allah menghakimi kita, melainkan karena kebenaran Ia membenarkan kita oleh iman. Injil tidak menunjukkan penghukuman dan murka Allah tetapi penyelamatan dan pembenaran-Nya (Lane, 1990: 130). Dengan kata lain, kebenaran Allah adalah rahmat Allah, yang menerima manusia berdosa dan putus asa, sekaligus menolak orang-orang yang memandang dirinya baik dan benar (Aritonang, 2016: 33). Kata Luther: "Aku mulai sadar, bahwa kebenaran Allah tidak lain dari pada suatu pemberian yang dianugerahkan-Nya kepada manusia untuk memberi hidup yang kekal kepadanya; dan pemberian kebenaran itu harus disambut dengan iman. Injillah yang menyatakan kebenaran itu, yakni kebenaran yang diterima oleh manusia, dan bukan kebenaran yang harus dikerjakannya sendiri. Dengan demikian, Tuhan yang rahmani itu membenarkan kita dengan rahmat dan iman saja” (Berkhof \& Enklaar, 1986: 125). W.J. Kooiman meringkas keyakinan Luther demikian:

Kebenaran yang disebutkan Paulus, bukanlah pembalasan yang adil dari Allah, itu adalah kebenaran yang dilimpahkan kepada orang percaya, jadi itu hanya ungkapan yang dalam untuk rahmat Allah. Allah mengaruniakan kebenaran kepada orang percaya itu, Allah dari sebab rahmatNya memandang dia benar sekalipun dia tidak demikian. Dan rahmat itu bukanlah sesuatu, yang harus kita cari, atau yang "dituangkan" kepada kita melalui sakramen, itu diberikan kepada orang yang percaya kepadaNya oleh karena Kristus. Kebenaran Kristus adalah milik saya-dari kepercayaan itu orang percaya boleh hidup dari rahmat Allah (Kooiman, 1986: 43).

Penemuan ini membawa perubahan besar dalam pandangan teologi Luther. Hal itu terjadi antara tahun 1511 dan 1514. Melukiskan perubahan dirinya itu Luther berkata: "Aku merasa diri seakan-akan diperanakkan pula, dan pintu Firdaus terbuka bagiku. Pandanganku terhadap seluruh Alkitab menjadi berubah sama sekali, karena mataku sudah celik sekarang" (Berkhof \& Enklaar, 1986: 125). "Segera setelah Luther melihat itu, ia merasa seperti lahir kembali dan masuk taman Eden", demikian Tony Lane mencatat Luther (Lane, 1990: 130).

Jadi, Luther mengembangkan gagasan teologis bahwa manusia diselamat- 
kan karena rahmat Allah saja dan itu diterimanya dalam iman, bukan karena melakukan perbuatan baik. Menurutnya, rahmat itu adalah pengampunan yang membebaskan. Allah mengenakan kepada kita kebenaran Kristus dan dari sebab itu memandang kita selaku orang-orang benar. Hukuman-Nya atas kesalahan kita maupun belas kasihan-Nya atas kebinasaan kita telah ditunjukkannya dalam salib Kristus. Di situ ia sendirilah yang menanggung segala sesuatu. Maka segala perhitungan dan amalan manusia menjadi hilang. Manusia hanya dapat lagi beriman, berarti percaya kepada firman yang membebaskan itu. "Allah tidak menuntut melainkan menganugerahkan" (End, 1982: 161). Inilah inti teologi Luther. Dengan demikian benarlah bila dikatakan bahwa "The heart of Luther's theology was that in Jesus Christ God has given Himself, utterly and without reserve, for us" (George, 1992: 59).

Bila diamati dengan saksama, sesungguhnya pandangan teologi Luther ini bukanlah sesuatu yang baru. Sebagaimana telah dikatakan bahwa semangat Renaisans mendorong penggalian terhadap sumber-sumber asli antara lain Alkitab dan tulisan para patristik. Oleh karena itu Luther tidak mendasarkan pandangan teologisnya pada Alkitab saja. Tetapi ia juga melihat bahwa pandangannya itu sudah diletakkan oleh para Bapa Gereja, khususnya Augustinus. Ini disebabkan oleh kenyataan bahwa abad-abad sebelum reformasi boleh dikatakan sebagai suatu "Agustinian Renaissance". Orang yang tertarik pada Renaisans akan mempelajari pandangan para patristik. Timothy George melukiskannya demikian:

Perhaps the most positive contribution of the humanist scholars to the religious renewal of the sixteenth century was the series of critical editions of the Bible and the Church Fathers which were widely disseminated due to the phenomenal success of the printing press. Erasmus' favorite Church Father was Jerome, but by far the most influential patristic source for Reformation theology was Augustine. Indeed, in the centuries just prior to the Reformation there was something of an "Augustinian Renaissance," spawned in part by a renewed interest in the theology of Augustine within the Augustinian Order itself and by the attraction to Augustine of early humanists such as Petrach, who was drawn especially to the Confessions. Whenever he would read it, he said, "it seems to me that I am reading not someone else's history, but the history of my own pilgrimage" (George, 1992: 48). ${ }^{4}$

4 Tentang Augustinus secara lengkap dan gagasan-gagasan teologinya dapat 
Berdasarkan pandangan teologi itu maka Luther memulai reformasi. Tindakan pertama yang dilakukannya adalah memasang 95 dalil di depan pintu gereja (kapel) di Universitas Wittenberg pada tanggal 31 Oktober 1517. 5 Dalil-dalil tersebut dimaksudkan sebagai sanggahan terhadap propaganda Tetzel dengan penjualan surat-surat penghapusan siksa. Isi dari dalil-dalil tersebut menentang perkataan Tetzel bahwa surat-surat yang ditawarkannya itu menghapuskan dosa dan memperdamaikan manusia dengan Allah, yang menimbulkan kesan seakan-akan pengampunan dosa dan pendamaian dapat dibeli dengan uang, tanpa penyesalan dan pertobatan, bahkan tanpa sakramen. Sekaligus dengan itu Luther menegaskan bahwa penyesalan yang sejati bukanlah perkara yang dapat seseorang bereskan dengan memenuhi syarat yang ditentukan oleh imam setelah pengakuan dosa, seperti misalnya mengucapkan doa Bapa Kami sekian banyak kali. Bagi Luther, penyesalan dan pertobatan itu berlangsung sepanjang hidup (Aritonang, 2007: 20).

Berkat percetakan yang telah ada, dalil-dalil Martin Luther dicetak dan tersebar luas dengan cepat. Segera pula terasa pengaruhnya yang besar. Gereja Roma terguncang. Para raja dan bangsawan yang telah lama merasa gelisah dengan kiprah kepausan bangkit mendukung Luther. Pro dan kontra terhadap gerakannya muncul di mana-mana. Ia terancam hukuman melalui pengadilan Gereja. Ia disuruh mencabut dan menarik kembali ajarannya. Namun ia tetap bersikukuh dengan pendiriannya dan dapat membela diri. "Di sini aku berdiri. Aku tidak dapat berbuat lain," (Aritonang 2016, 36), demikian ia bersaksi di hadapan pengadilan. Dalam perjalanan menuju takhta pengadilan di luar wilayah Saksen, orang-orang berteriak "Balik, balik!". Tetapi ia menjawab: "Di sana pun berkuasa Kristus. Semoga Kristus hidup, Martinus binasa, bersama dengan setiap orang berdosa!" (End, 1982: 168). Paus kemudian mengeluarkan bulla yang berisi kutukan kepadanya dan ajarannya dipandang sesat. Namun, pengaruhnya terus dirasakan semakin meluas.

Melalui tulisan-tulisannya yang terbit sejak tahun 1520, pandangan dan

dibaca dalam buku Augustinus, Pengakuan-Pengakuan, (Agustinus, 1997); Juga buku, Augustinus Tahanan Tuhan, (Diepen, 2000).

5 Dalam waktu dekat, BPK Gunung Mulia akan menerbitkan buku berisi 95 dalil Martin Luther secara lengkap. 
gagasan-gagasan teologinya sampai kepada kalangan yang lebih luas. Di sini patut dicatat beberapa karangannya yang terkenal antara lain berjudul: (1) Kepada Para Pemimpin Kristen Jerman-Mengenai Perbaikan Masyarakat Kristen; (2) Preludium tentang Pembuangan Babel untuk Gereja; (3) Kebebasan Seorang Kristen. Karangan yang pertama berbicara tentang imamat am orang percaya sebagai kritik terhadap klerikalisme; karangan kedua membahas sakramen yang dalamnya ditegaskan bahwa hanya ada dua sakramen yang ditetapkan Kristus dan bahwa sakramen bukanlah saluran anugerah sebagai penjamin keselamatan; karangan ketiga tentang etika Kristen. Dalam karangan yang terakhir ini terdapat pernyataan yang terkenal dan terkesan paradoksal dari Luther tentang seorang Kristen: "Seorang Kristen bebas dari segala ikatan dan bukan hamba dari siapapun; Seorang Kristen terikat pada segala sesuatu dan hamba pada semua orang”(Aritonang, 2016: 36-37).

Gelombang reformasi terus berayun. Sementara reformasi Martin Luther berjalan, beberapa gerakan reformasi radikal yang telah lama terpendam, muncul ke permukaan dengan kecenderungan radikalismenya. Patut disebutkan di sini dua kelompok yakni gerakan yang dipelopori oleh Thomas Muenzer dan gerakan Anabaptis Radikal. Kedua-duanya menyetujui kekerasan sebagai jalan melakukan pembaruan. ${ }^{6}$ Luther dan Calvin menghadapi kedua gerakan reformasi radikal ini dan keduanya mempunyai sikap sendiri-sendiri terhadapnya. Dalam hal ini yang penting disadari adalah reformasi yang dicanangkan dan dijalankan oleh Luther berdampak besar bagi pembaruan gereja dan bahkan pada tatanan masyarakat kala itu.

Mungkin dapat timbul pertanyaan, apakah dengan reformasi Luther hendak mendirikan sebuah gereja baru yaitu Gereja Reformasi? Sesungguhnya tidak ada niat pada Luther, begitu juga Calvin untuk membentuk gereja baru di samping dan berbeda dengan Gereja Roma. Yang Luther kehendaki hanyalah pembaruan pada ajaran dan praktik gereja yang menurutnya telah menyimpang dari Alkitab. Mereka hanya ingin memurnikan ajaran gereja. Sebagaimana dikatakan oleh Jean Cadier berikut ini:

He wished to restore to the church its apostolic character, to recover an the ancient state of which the Fathers speak, to raise up the ruins, to restore their

6 Tentang gerakan Anabaptis dapat dibaca dalam buku Calvin and the Anabaptist Radicals (Balke, 1981). 
primitive splendor things which have been depraved and dissipated in the church. Calvin wanted the reformation of the church, her renewal, and not a division. He wanted a purified church, not a new church. (Cadier 1966, 119).

Bahkan Luther tidak menghendaki namanya diacu oleh orang-orang protestan pada permulaan reformasi untuk menunjukkan identitas mereka. Kutipan berikut ini menjelaskan hal dimaksud:

Far from attempting to found a new sect, Luther always saw himself as a faithful and obedient servant of the church. Thus his deep chagrin that the first Protestants, in England and France no less than in Germany, were being called "Lutherans."(George, 1992: 53).

Dalam salah satu tulisannya ia malah menegaskan:

The first thing I ask is that people should not make use of my name, and should not call themselves Lutherans but Christians. What is Luther? The teaching is not mine. Nor was I crucified for anyone... How did I, poor stinking bag of maggots that I am, come to the point were people call the children of Christ by my evil name? (George, 1992: 53).

Karena itu, seandainya Gereja tradisional di Roma waktu itu menerima reformasi maka tidak akan ada Gereja Protestan yang di kemudian hari dikenal sebagai Gereja Lutheran dan Gereja Calvinis beserta berbagai aliran yang muncul sesudahnya.

\section{Relevansi Reformasi Abad ke-16 bagi Transformasi Masyarakat Indonesia}

Di Indonesia, istilah reformasi pernah menjadi euforia. Akan tetapi reformasi di Indonesia bukanlah reformasi keagamaan melainkan reformasi politik pemerintahan dan kenegaraan. Tatkala rezim Orde Baru dipandang tidak memadai lagi sebagai orde politik yang menolong untuk mengatasi berbagai ketimpangan dalam kehidupan masyarakat Indonesia, semangat reformasi muncul di mana-mana. Dipelopori oleh mahasiswa bangkitlah gerakan rakyat pada tahun 1998 untuk menumbangkan pemerintahan Orde 
Baru. Tentu saja reformasi tahun 1998 itu dilatarbelakangi oleh alasanalasan yang kuat. Alasan-alasan itu antara lain maraknya korupsi, kolusi, dan nepotisme $(\mathrm{KKN})$ terutama di kalangan birokrasi, pemerintahan yang otoriter dengan mengandalkan kekuatan senjata, terpasungnya demokrasi, keterpurukan ekonomi, pelanggaran hak asasi manusia dan ketidakadilan yang terjadi di mana-mana. A.A. Yewangoe mensinyalir ada dua alasan yang menyebabkan Orde Baru pada akhirnya runtuh. Alasan-alasan dimaksud adalah: (1) terjadinya pegeseran dalam bidang ekonomi dari apa yang disebut "Wijoyonomics" ke "Habibienomics"; (2) arogansi kekuasaan di bidang politik (Yewangoe, 1999: 21-23). Tentang arogansi kekuasaan Yewangoe lebih jauh mengatakan bahwa almarhum T.B. Simatupang sebenarnya sudah memperingatkan hal ini sebelum ia meninggal dunia. Menurut Simatupang, ada tiga hal yang menyebabkan kegagalan Orde Lama yang patut menjadi pelajaran bagi Orde Baru yakni: (a) ketidakrendahan hati untuk mengadakan koreksi dan pembaruan dari diri sendiri; (b) ketidakrendahan hati untuk mengembangkan mekanisme pengawasan terhadap diri sendiri; (c) ketidakrendahan hati untuk mengembangkan suksesi terhadap diri sendiri (Yewangoe, 1999: 23).

Apa yang dikatakan Eddy Paimon kurang lebih sejalan dengan sinyalemen Yewangoe di atas. Menurutnya, setelah para ahli menyelidiki dengan saksama fenomena reformasi di Indonesia maka ternyata ditemukan bahwa yang menjadi akar dari semua permasalahan yang serius itu adalah penyalahgunaan kewibawaan dan kekuasaan. Kesemuanya itu menyatu dengan ambisi sekelompok kecil para penguasa dan konglomerat yang mempunyai tujuan hanya untuk memperkaya diri sendiri. Dalam usaha memperkaya diri ini, para penguasa dan golongan pengusaha bersembunyi di balik topeng Pancasila dan UUD 1945. Untuk mencapai tujuan kotor itu, mereka telah menggunakan sistem nepotisme yang melegalkan segala cara seperti kolusi dan korupsi dalam segala bidang (Paimon, 1999: 40).

Orang-orang itu menurutnya bahkan tidak segan-segan memperalat agama sebagai lembaga legalistik untuk melegitimasi dan membenarkan tindakan mereka agar memperoleh dukungan moral. Para penguasa telah memperalat agama untuk mencapai tujuan, meskipun bertentangan dengan nilai-nilai moral etik. Hal ini dapat dibuktikan dalam perjalanan 32 tahun Orde Baru. Kekuasaan dan agama saling memperalat dan diperalat untuk 
kepentingan kelompok tertentu (Paimon, 1999: 40-41).

Bila kita memperbandingkan motif-motif di balik reformasi abad ke16 di Eropa dan reformasi abad ke-20 di Indonesia, kita akan menemukan realitas-realitas atau kecenderungan-kecenderungan yang kurang lebih sama, kendati dalam esensinya keduanya berbeda. Yang satu merupakan reformasi keagamaan, yang lain adalah reformasi di bidang politik kenegaraan. Kondisi sosio-religius, politik dan ekonomi serta kebudayaan, arogansi penguasa yang berwujud dalam penyalahgunaan kewibawaan dan kekuasaan, kecenderungan menggunakan dan memperalat agama untuk melegitimasi kebijakan demi mencapai ambisi tertentu dan kepentingan sendiri mewarnai kedua reformasi di atas. Kedua reformasi tersebut pada gilirannya membawa perubahan pada tatanan masyarakat. Dengan kata lain, kedua reformasi tersebut membawa transformasi masyarakat.

Oleh karena itu, reformasi di Indonesia, meskipun pada dasarnya bukan reformasi keagamaan, dapat berkaca pada reformasi abad ke-16 dalam rangka melihat relevansinya bagi transformasi masyarakat Indonesia. Menurut saya, sejarah panjang reformasi abad ke-16 menyadarkan kita akan beberapa hal yang dapat menjadi bahan pelajaran bagi transformasi masyarakat Indonesia pasca reformasi tahun 1998. Hal-hal dimaksud adalah: Pertama, bilamana kita ingin mengubah wajah sebuah masyarakat serta tatanan kehidupannya di berbagai bidang kehidupan agar berkembang baik dan terhindar dari keterpurukan maka yang perlu kita lakukan adalah mengadakan reformasi. Transformasi masyarakat dapat terjadi bila reformasi dilakukan. Tanpa reformasi, sulit dibayangkan transformasi kehidupan gereja dan masyarakat dapat terjadi. Reformasi di Indonesia berhasil mengubah wajah masyarakat Indonesia di bidang politik, hukum dan sosial kemasyarakatan dari otoriterisme kepada demokrasi, dari korupsi kepada transparansi, dari ketidakadilan hukum kepada hukum yang berkeadilan, dan seterusnya. Penting di sini untuk ditekankan bahwa reformasi bukanlah revolusi.

Kedua, reformasi untuk transformasi masyarakat tidaklah selamanya berarti menghadirkan suatu idealisme baru ke dalam kenyataan buruk yang sedang dan sudah ada. Reformasi untuk transformasi juga bisa dilakukan dengan kembali ke kejayaan masa lalu atau kembali ke sumber-sumber yang asli dan menjadikannya sebagai kekuatan perubahan. Transformasi gereja dan masyarakat abad ke-16 dapat terjadi justru karena para pelopor 
reformasi kembali kepada sumber-sumber yang asli dan utama yakni Alkitab dan pemikiran para patristik. Semboyan ad fontes penting di sini. Jadi, yang lama yang nyaris terlupakan atau sengaja dilupakan, dapat menjadi "kekuatan peubah" baru yang dahsyat. Di sini reformasi demi transformasi dapat pula berarti "melawan lupa".

Ketiga, tatkala agama dipakai sebagai alat legitimasi kekuasaan untuk kepentingan politik, baik jangka pendek maupun jangka panjang, maka terbukalah ruang penyalahgunaan kewibawaan dan kekuasaan yang bisa kronis. Bahkan tidak hanya kronis. Ibarat penyakit, ia dapat berakibat kematian. Karena itu, untuk menghindarkan diri dari penyelewengan kewibawaan dan kekuasaan maka kita harus mampu menempatkan agama dan politik pada jalurnya masing-masing serta menggunakannya secara proporsional. Persoalan besar bangsa kita sekarang ini adalah bahwa agama dan politik telah bagaikan tali-temali yang terikat erat nyaris tak kelihatan ujungnya dan sulit terurai. Keduanya saling melegitimasi. Itulah sebabnya dalam setiap masalah kebangsaan dan kenegaraan nyaris terlihat kaitan agama di dalamnya. Maka transformasi masyarakat Indonesia pada dewasa ini dapat berarti membebaskan agama dari penggunaannya secara keliru di ranah politik. Sebaliknya menjadikannya kekuatan dan sumber inspirasi yang menarik politik kembali kepada relnya yakni memanusiakan kehidupan demi hidup yang sejahtera.

\section{Kesimpulan}

"Reformasi merupakan jawaban iman terhadap proses perubahan yang sedang menantangnya, namun sekaligus juga benar bahwa reformasi telah membawa perubahan sosial. Bagaimana hal itu terjadi dapat kita lihat pada riwayat Luther dan Calvin serta dampak kehadiran mereka dalam sejarah,” demikian pernyataan Emanuel Gerrit Singgih dalam bukunya Reformasi dan Transformasi Pelayanan Gereja (Singgih, 1997: 49). Pernyataan Gerrit Singgih ini dapat menjadi kesimpulan kita yang pertama.

Kesimpulan yang kedua ialah bilamana dewasa ini kita menghendaki terjadinya transformasi dalam masyarakat Indonesia maka kita perlu ingat kepada ad fontes. Berkenaan dengan pemanfaatan agama sebagai alat legitimasi politik, tingkat intoleransi yang semakin tinggi, fanatisme serta radikalisme 
agama yang berujung terorisme, rasa persatuan dan kesatuan selaku satu bangsa yang semakin memudar, kesadaran pluralitas yang menipis, kecenderungan menggantikan dasar negara dengan agama, ad fontes dapat menolong. Ad fontes bagi kita di Indonesia adalah kembali kepada Pancasila, Undang-undang Dasar 1945, Bhinneka Tunggal Ika dan Negara Kesatuan Republik Indonesia (NKRI). Kita harus berjuang melawan lupa dengan kembali kepada empat pilar kebangsaan yang telah membuat kita eksis sebagai sebuah bangsa hingga sekarang. Transformasi masyarakat Indonesia hendaknya mengarah ke sana. Kita harus berjuang keras melawan lupa, lupa pada Pancasila, lupa pada Undang-Undang Dasar 1945, lupa pada Bhinneka Tunggal Ika dan lupa pada NKRI. Berbagai persoalan bangsa akhir-akhir ini dapat kita selesaikan dengan cara ini yaitu kembali kepada keempat pilar kebangsaan. Dalam kaitan itu, kita patut menghargai upaya pemerintah membentuk Unit Kerja Presiden untuk Pembinaan Ideologi Pancasila (UKP-PIP) sebagai upaya penanaman kembali ideologi Pancasila yang seolah nyaris terlupakan.

Kesimpulan yang ketiga ini ingin saya kaitkan dengan kiprah rekan, sahabat, dan kakak bagi saya, Pdt. Prof. Dr. Samuel Benyamin Hakh ketika ia memimpin GPI yang dalamnya saya turut serta. Ada masa-masa kritis dalam Gereja Protestan di Indonesia (GPI) menyangkut asset GPI yang telah diserahkan pemanfaatan dan pendayagunaannya kepada Gereja Bagian Mandiri (GBM) tertentu. Keadaan ini menimbulkan ketegangan antara Badan Pelaksana Harian GPI dan Sinode GBM dimaksud. Bagaimana mengatasi ketegangan itu? Ia (Pak Sem demikian kami biasa menyapanya) mencetuskan gagasan perlunya meletakkan pemahaman tentang landasan teologis, historis, dan eklesiologis tentang GPI. Dengan begitu ia mengajak Gereja-Gereja Bagian Mandiri dalam GPI untuk kembali kepada sejarah, kepada masa lalu GPI dengan segala keputusannya yang dapat dijadikan sumber inspirasi dalam meminimalisasi ketegangan yang ada. Dengan kata lain, ia mengajak seluruh GPI untuk "ad fontes", kembali kepada sumbersumber sejarah masa lalu untuk mengatasi problematika masa kini. Dengan cara demikian, GPI berhasil keluar dari ketegangan. Jadi, boleh dikatakan bahwa konsep mengenai landasan teologis, historis, dan eklesiologis GPI merupakan buah peninggalan Pak Sem ketika memimpin GPI. Selamat memasuki usia yang ke-65. Tetaplah setia menjadi hamba-Nya dan hamba Gereja-Nya. 


\section{Daftar Acuan}

Augustinus, 1997. Pengakuan-Pengakuan., (terj.), Jakarta-Yogyakarta: BPK Gunung Mulia \& Kanisius.

Aritonang, Jan S. 2007. Garis Besar Sejarah Reformasi.Bandung: Jurnal Info Media.

Aritonang, Jan S. 2016. Berbagai Aliran Di Dalam Dan Di Sekitar Gereja. Jakarta: BPK Gunung Mulia.

Balke, Willem. 1981. Calvin and the Anabaptist Radicals. Grand Rapids: Eerdmans Publishing Company.

Batlajery, Agustinus M.L. 2010. The Unity of the Church according to Calvin and it's meaning for the Churches in Indonesia.Disertasi., Free University.

Berkhof H. \& I.H. 1986. Enklaar, Sejarah Gereja. Jakarta: BPK Gunung Mulia.

Cadier, Jean. 1966. "Calvin and the Union of the Church." In John Calvin $A$ Collection of Essays., ed. G.E. Duffield.Grand Rapids: Eerdmans Publishing Company.

Diepen, P. van. 2000. Agustinus Tahanan Tuhan, Yogyakarta: Kanisius.

End, Th. Van den. 1982. Harta Dalam Bejana. Jakarta: BPK Gunung Mulia. George, Timothy. 1992. Theology of the Reformers. Nashville: Broadman Press. Kooiman, W. J. 1986. Martin Luther, (terj.), Jakarta: BPK Gunung Mulia.

Kristiyanto, Eddy. 2002. Gagasan Yang Menjadi Peristiwa. Yogyakarta:

Kanisius.

Lane, Tony. 1990. Runtut Pijar, (terj.), Jakarta: BPK Gunung Mulia.

McGrath, Alister C. 1997. Sejarah Pemikiran Reformasi, (terj.), Jakarta: BPK Gunung Mulia.

Paimon, Eddy. 1999. "Gereja Dalam Era Reformasi di Indonesia." Dalam Gereja dan Reformasi Pembaruan Gereja Menuju Indonesia Baru., peny. Victor Silaen. Jakarta: Yakoma PGI.

Singgih, Emanuel Gerrit. 1997. Reformasi dan Transformasi Pelayanan Gereja Menyongsong Abad ke-21. Yogyakara: Kanisius.

Tanner, Norman P. 2003. Konsili-Konsili Gereja Sebuah Sejarah Singkat. 
Yogyakarta: Kanisius.

Yewangoe, A. A. 1999. "Gereja di Era Reformasi." Dalam Gereja dan Reformasi Pembaruan Gereja Menuju Indonesia Baru., peny. Victor Silaen. Jakarta: Yakoma PGI. 